\title{
VISCERAL SYPHILIS
}

\author{
SYPHILIS OF THE PANCREAS *
}

UDO J. WILE, A.B., M.D.

Professor of Dermatology and Syphilology, University of Michigan

ANN ARBOR, MICH.

The pancreas is a common site of election for syphilis of the newborn, but clinical syphilis of the pancreas in the acquired form must be regarded as one of the rarest of visceral manifestations. Rokitansky $^{1}$ was the first to call attention to the occasional association of syphilitic pancreatitis with syphilitic hepatitis. Later Lancereaux ${ }^{2}$ mentions its association also with other forms of visceral syphilis. Cases demonstrated at necropsy, in which the diagnosis was not suspected intra vitam, have been reported by Chvostek, ${ }^{3}$ Drozda, ${ }^{4}$ Schlagenhaufer, ${ }^{5}$ Steinhaus, ${ }^{6}$ Rosenheim, ${ }^{7}$ Kovacs, ${ }^{8}$ and Leuret and Secousse. ${ }^{9}$ According to Neumann, ${ }^{10}$ the diagnosis is practically never made during life, or at least without operation. I have been able, however, to find a number of cases in which undoubted syphilis of the pancreas was diagnosed intra vitam. Such cases are reported by Moynihan, ${ }^{11}$ Michaloff,, ${ }^{12}$ Singer, ${ }^{13}$ Wolff, ${ }^{14}$ Trinkler, ${ }^{15}$ Jevinici, ${ }^{16}$

* Studies and Contributions of the Department of Dermatology and Syphilology of the University of Michigan, service of Dr. Udo J. Wile.

1. Rokitansky: Lehrbuch der Pathologische Anatomie 3:254 and 255.

2. Lancereaux: Traite de Syphilis, 1874, p. 254.

3. Chvostek: Wien. med. Wchnschr. 1877, No. 33.

4. Drozda: Wien, med. Presse, 1880.

5. Schlagenhaufer: Einfall von Pankreatitis syphilitica indurativa et gummosa aquisita, Arch. f. Dermat. u. Syph. 34:44, 1895.

6. Steinhaus, cited by Walter-Sallis, reference No. 20: Soc. Anat. Path. du Belge, 1907.

6. Steinhaus: Soc. Anat. Path. du Belge, 1907.

7. Rosenheim: Ueber Einen Fall von Chronischen Interstitielen Pankreatitis, Berl. klin. Wchnschr., No. 35:317, 1898.

8. Kovacs, cited by Zerfing, Southern Calif. Practitioner 23:199, 1908.

9. Luret and Secousse: Sur un cas de syphilis tertiare du pancréas s'accompagnant de compression de la veine porte, Gaz. hebd. d. sc. méd de Bordeaux 35:104, 1914.

10. Neumann: Syphilis, Spezielle Pathologie und Therapie, in Nothnagel's System, Ed. 2, 1899, p. 433.

11. Moynihan: Some Cases of Chronic Pancreatitis, Lancet, No. 2:856, 1902.

12. Michaloff, cited by Charmaux, Thése de Paris, 1894.

13. Singer, G.: Zur Klinik der kronischen Pankreasaffektionen, Wien. med. Wchnschr. 60:2605, 1910.

14. Wolff, E.: Pankreascysten u. Pseudocysten, Beitr. z. klin. chir. 74:487, 1911.

15. Trinkler, N.: Zur Diagnose der Syphilischer Affectionen des Pankreas, Deutsch. Ztschr. f. Chir., No. $75:$ 58, 1904.

16. Jevinici, cited by Walter Sallis, Ann. de dermat. et syph., Ser. 5, 4:665, 1913. 
Umber, ${ }^{17}$ Kretschmer ${ }^{18}$ and Strauss. ${ }^{19}$ With the exception of Walter Sallis, ${ }^{20}$ clinicians agree that the condition is exceedingly rare. Of 188 cases of pancreatic disease studied by Oser, ${ }^{21}$ only three were cases of pancreatic syphilis. Walter Sallis, however, who has written an extensive monograph on the subject, asserts that the condition is not so rare, and cites the fact that syphilitic lesions occurred in the pancreas fortyfive times in 100 cases of abdominal syphilis. He was able, however, to collect only fifteen cases of clinical pancreatitis. The belief in the rarity of the condition as outlined above is not shared by Warthin, ${ }^{22}$ who, in an article written in 1916 ard in subsequent publications, says that he believes that chronic interstitial pancreatitis is one of the most frequent visceropathies found at necropsies in cases of latent syphilis. He states that syphilis is the most common cause of interstitial, interlobular and interacinar pancreatitis, and suggests an etiologic relationship between such pancreatitis and diabetes mellitus.

\section{INCIDENCE}

According to most authors, syphilis of the pancreas occurs in a sclerous and a gummatous form. I have, however, been able to find two cases in which definite cysts occurred, undoubtedly due to the absorption of gummatous lesions. The condition occurs, therefore, as a gummatous or nodular pancreatitis and as an interstitial pancreatitis. A combination of both of these forms is also found.

\section{SYMPTOMS}

The symptoms of syphilitic pancreatitis differ but slightly from those of other pancreatic diseases. For this reason, according to Neumann, a differential diagnosis is almost impossible. A careful scrutiny, however, of the few cases reported shows some slight differences in the symptomatology from other forms of pancreatic disease in a few cases. Most cases are indistinguishable as syphilitic. The pancreas is so seldom alone involved that the symptoms are frequently masked by those of involvement of the adjacent viscera.

17. Umber: Zur Viszeralen Syphilis (Pankreatitis syphilitike mit Diabetis, akute gelbe Leberatrophie und ihrer heilung durch Salvarsan), München. med. Wchnschr. 58:2499, 1911.

18. Kretschmer, J.: Die Vielgestaltigkeit der Viszeralen Lues, Deutsch. med. Wchnschr. 36:835, 1910.

19. Strauss, H.: Hochgradige Pankreas-Atrophie bei Diabetis, Berl. klin. Wchnschr. 48:40, 1911.

20. Sallis, Walter: Ann. de dermat. syph., Ser. 5 4:657, 1913.

21. Oser: Ztschr. f. klin. Med. 26:191, 1894.

22. Warthin: Syphilis of the Pancreas, with Reference to the Coincidence of Syphilitic Pancreatitis and Diabetes, Tr. Assn. Am. Phys. 31:387, 1916. 
Pain.-As in other cases of pancreatic disease, pain is a predominating symptom. It has, however, no characteristic. In some cases it is identical with that of cholelithiasis, radiating to the shoulder and suggesting in its paroxysmal character, typical gallstone colic.

Functional Disturbance.-Functional disturbance of the pancreas has been noted in a few cases. Rosenheim ${ }^{7}$ and Umber ${ }^{17}$ report practical absence of protein digestion and associated fatty stools. Fat in the stools is also recorded in one of the cases reported by Singer. ${ }^{13}$

Glycosuria.-Glycosuria occurred in eight cases, and Walter Sallis ${ }^{20}$ insists that syphilis of the pancreas is distinctly "diabetogenous." $\mathrm{He}$ also mentions steatorrhea as strongly suggestive of pancreatic syphilis. Glycosuria is usually slight; in a few cases it is severe, the percentage being as high as 7.6 in one case reported by Wolff. ${ }^{14}$ Maltosuria occurred in one case reported by Rosenheim. ${ }^{7}$

Fever.-Fever occurred in a fair percentage of the cases mentioned and is also of some diagnostic value as differentiating chronic pancreatitis.

Tumor.-Of the fifteen cases collected by Walter Sallis, ${ }^{20}$ tumor occurred in eight, and therefore must be considered as a suggestive finding in syphilis of the pancreas. Emaciation is present in a few cases, but is never so severe as in malignant neoplasm.

Icterus.-Icterus was found in almost every case of pancreatic syphilitic disease. It may be due to pressure on the common duct by a gumma of the head of the pancreas or as frequently may be due to associated hepatic syphilis. Clay colored stools are reported in those cases in which obstructive jaundice occurred.

Gastro-intestinal Disturbances.-Vomiting and nausea, fat diarrhea, meteorism and colic occur as they do in other forms of pancreatic disease.

To sum up, there are no direct pathognomonic symptoms of syphilis of the pancreas. The few points suggestive of syphilis when the pancreas is the seat of the disease are jaundice without other cause, glycosuria and tumor of the pancreas without cachexia.

\section{DIAGNOSIS}

The differential diagnosis is extremely difficult. The cases must be distinguished from carcinoma of the head of the pancreas, from cholelithiasis and from chronic interstitial pancreatitis. Except for the predominance of glycosuria in syphilis (in about 50 per cent. of the cases) and the relatively mild cachexia in association with large palpable tumor, there are no definite criteria to differentiate syphilis of the pancreas from other forms of pancreatic disease. The association, however, of hepatic disease, or of any other form of syphilis, points 
strongly toward syphilis as the cause of pancreatic disease when such can be demonstrated; and it is worthy of note that most of the cases of pancreatic disease have been associated with other forms of syphilis. Lastly, the therapeutic test has proved the most efficient diagnostic aid in the majority of cases.

\section{PROGNOSIS}

According to Neumann, ${ }^{10}$ the prognosis is unfavorable, as most of the cases are recognized only during the postmortem examination. With, however, the routine Wassermann test performed on all patients, the prognosis should be more favorable. In the cases that I have been able to collect from the literature, complete recovery is reported as a result of the administration either of arsphenamin, mercury or iodid, or of mercury and iodid combined, in ten cases: those of Moynihan, ${ }^{11}$ Michaloff, ${ }^{12}$ Wolff,, ${ }^{14}$ Trinkler, ${ }^{15}$ Jevinici, ${ }^{16}$ Umber, ${ }^{17}$ Kretschmer ${ }^{18}$ and three of Singer's ${ }^{13}$ cases. 